\title{
Adapting Competitiveness and Gamification to a Digital Platform for Foreign Language Learning
}

\author{
https://doi.org/10.3991/ijet.v15i20.16135
}

\author{
Norman Patrick Harvey Arce $\left({ }^{\bowtie}\right)$, Ana Maria Cuadros Valdivia \\ Universidad Nacional de San Agustín de Arequipa, Arequipa, Peru \\ nharvey@unsa.edu.pe
}

\begin{abstract}
Due to globalization growth, learning a second language is a necessity to develop in an increasingly demanding multicultural environment. However, at present we still find that some traditional methodologies are still being applied for teaching, which represents a problem for current students, also called digital natives, because these methodologies should adapt to this digital age of technology and knowledge. To solve this problem, a digital resource for foreign language learning was developed taking into account competitiveness and gamification as bases to motivate students and engage them into the course. The objective of this tool is to improve the processing of theoretical information obtained making use of a virtual environment which has competitive activities and gamification elements such as: obtaining medals for completing tasks, user's progress bar and ranking according to the scores obtained, so that students are motivated and improve their learning. This research seeks to analyze the effects of applying competitiveness and gamification in a virtual environment aimed at foreign language learning. It was found that $81.03 \%$ of students are more inclined to use gamified digital tools and also $82.76 \%$ of students feel more motivated to learn a second language using this methodology.
\end{abstract}

Keywords - Gamification, Competitiveness, Gamified Platform, Foreign Language Learning, Educational Technology.

\section{Introduction}

In a society that is constantly growing by globalization, language proficiency is no longer optional but necessary. One of the main reasons for its importance is that it is essential to understand and share information in a language that everyone can understand, and for this, English is used as main language in results dissemination [1] and multi-disciplinary research [2], [3].

This cognitive process of language acquisition varies in each person and that is why new teaching strategies must be applied in order to cover all the different ways of processing the information obtained. Also, for this digital age of knowledge we have "digital natives", named because they were born in the age of technology [4] as a part of society that has grown hand in hand with technological advances and therefore requires a different way of learning [5], [6]. 
In this sense, some teaching strategies have evolved over time and they are taking into account technology as an additional resource for use in class [7]. Thus, there are investigations whose objective is to develop innovative teaching methods such as modeling of technology for education [8]-[11], and even the use of some new trends such as: social and semantic web [12], learning objects, augmented reality and immersive environments (such as video games and virtual platforms) [13].

However, personal motivation is not given the necessary importance at the time of developing these tools, being a main factor to consider in these studies since there is a high risk of dropping out learning by students [14] because these tools focus on the administration of the course and its contents [15], and do not pay attention on how to keep the student's commitment constant [16]. This is the main problem for a student when using an educational platform. Table 1 indicates some factors that lead to dropping out of the course.

Table 1. Factors involved in dropout of e-learning platforms.

\begin{tabular}{|l|l|l|}
\hline \multicolumn{1}{|c|}{ Author(s) } & \multicolumn{1}{|c|}{ Research } & \multicolumn{1}{c|}{ Factors } \\
\hline Jordan K. (2015) & $\begin{array}{l}\text { Massive Open Online Course } \\
\text { Completion Rates Revisited: } \\
\text { Assessment, Length }\end{array}$ & $\begin{array}{l}\text { Lack of motivation at the beginning of the course in } \\
\text { the first two weeks (key time to get the commit- } \\
\text { ment), start date, duration of the course. }\end{array}$ \\
\hline $\begin{array}{l}\text { Gomez-Zermeno, } \\
\text { M.; Aleman, L. } \\
(2016)\end{array}$ & $\begin{array}{l}\text { Research Analysis on MOOC } \\
\text { Course Dropout and Retention } \\
\text { Rates }\end{array}$ & $\begin{array}{l}\text { Lack of tutorials, time. Content quality, difficulty } \\
\text { with the structure of the course, limitations in the } \\
\text { use of technology or language, platform limitations. }\end{array}$ \\
\hline $\begin{array}{l}\text { Rothkrantz, L. } \\
(2017)\end{array}$ & $\begin{array}{l}\text { Dropout Rates of Regular } \\
\text { Courses and MOOCS }\end{array}$ & $\begin{array}{l}\text { Lack of motivation, advice, time. Courses difficulty, } \\
\text { activities last a long time, differs from expectations, } \\
\text { limited skills, less social contact. }\end{array}$ \\
\hline
\end{tabular}

There are several proposals to solve this problem, one of them being "gamification", which makes use of videogame design elements in a different context in order to motivate and engage students [17], [18], in learning process [19], [20].

In recent research it is concluded that gamification has a positive effect on behavior [21]; according to [22], there are some gamification elements that involve specific psychological aspects such as that obtaining medals and rewards involves personal satisfaction and desire to win; also [23] indicate that the use of these new tools arouses the curiosity of students generating a certain commitment to discover new things, which serves as main element in student motivation [24].

In addition, we find several case studies that demonstrate the success of using this proposal, as is the case of online courses offered on virtual platforms (MOOC: Massive Open Online Course) in which gamification plays an important role in their success [25], [26], by influencing the student in a positive way [27], [28] and being capable of adapting these tools to an specific case [29]. Additionally we could mention other research projects which uses gamification for teaching advanced courses, achieving positive results regarding student's learning [30], for example a course for Descriptive Geometry for Architecture [31] or programming courses [32].

Also, competitiveness is used as one of the main factors to be taken into account for this research, since it has been shown that students develop their cognitive skills 
better in a competitive context to improve their overall performance [33] and optimize the execution of certain activities through gamification [34].

Thus, we have that gamification has rapidly became a subject studied by different fields of research and it still continues to be relevant for them. One of these fields, and the one covered in this research, is foreign language learning.

The problem we found is that traditional and best-known methods that exist dedicated to language education, focus only on the distribution of content without taking into account an important factor such as motivation, whose absence not only affects low learning but also the demotivation that the student feels along with problems such as: lack of confidence, discouragement to continue learning and lack of commitment [35], ending with attrition and abandonment in language learning [36]. Furthermore, there are still gaps in this field that must be solved and this is why this problem is still relevant at this time.

The objective of this research is to analyze the effects resulting from providing a digital resource that reinforces the processing of information acquired in English language learning and whose activities are mainly based on competitiveness. This tool serves as an additional resource to motivate the student in the learning process by applying gamification. Its significance to the field lies in showing that motivation and competitiveness are important factors to take into account when developing these tools.

Also, in order to analyze the effects resulting from the use of a gamified digital resource based on competitiveness aimed at language learning, the following research questions were established:

- Regarding gamification

- R.Q.S.1. Can a better learning, by using a gamified digital tool, be verified?

- R.Q.S.2. Is the expected motivation achieved in students?

- R.Q.S.3. How do students perceive the use of these digital resources?

- Regarding competitiveness

- Is the application of competitiveness relevant in this process?

- In this methodology, does competitiveness among students improve learning?

\section{Theoretical Framework}

\subsection{Competitiveness}

The premise of obtaining a benefit is what encourages competitive people to outdo themselves and others [37], and also requires a certain level of commitment to the activity in order to complete it. This satisfaction of being in first places [38] is a kind of motivation that is implicitly present in video games, since there are some specific elements in them that produce a benign effect on the psychological need for personal satisfaction [39]. Because users strive to win and, in this way, compete "playing" 
[40], it is that competitiveness is considered one of the main factors in student motivation.

This tool has a ranking system which compares not only user scores but also medals obtained throughout the progress of the activities. The system is updated every time a new record is saved in the score table and medals number table.

\subsection{Motivation}

Table 1 shows that the most common dropout factor in e-learning platforms is the lack of motivation among others [41], since these platforms focus more on the distribution of course content and not on motivating students so that they can be engaged with the development of activities. We consider it as a main factor because through motivation, the student should be engaged to obtaining better results when learning.

To achieve this engagement in students, activities are implemented that meet their psychological and social needs [42], [43], in order to feel committed without any conditioning. Thus, according to the theory of self-determination [44] we can distinguish two types of motivation according to the objectives they pursue.

Intrinsic motivation: It refers to performing an activity independently, either because it is fun or because there is an interest in persons in satisfying their personal psychological needs. To achieve this motivation, the platform uses video game elements like: scores, challenges, and levels that pose a challenge to overcome [45]. Word repetition activities are included as these exercises have the ability to make students learn indirectly by repeating words and associate them with an action or object [46].

Extrinsic motivation: External stimuli that a person has when performing an activity such as being recognized by others. The platform uses incentives such as virtual medals and assistance through collaboration and competition activities [39], [40], which serve as positive reinforcement to meet the students' personal external needs.

To understand how gamification is used in non-recreational activities, it is necessary to understand how the games manage to capture the attention of the players. According to [47], we can compare game design with committed learning, since both have similar characteristics such as: goal-oriented, challenging tasks, standards in the way of solving a problem, reinforcement by some mistake made, performance affirmation, cooperation with others, novelty and variety, and possibility of choice.

\subsection{Narrative}

The narrative is the way to tell a story from the point of view of a character within a video game and that can include different plots depending on the actions performed by the player [48]. As told by [49], it is possible to learn by doing pleasant and entertaining activities, such as watching a movie, reading a book or watching a theater play. These activities teach a message indirectly, which is received by those who perform these activities, who in turn take a role of spectators but not participants. In order to provide this participation, this research uses a gamified digital tool to support the interaction between the student and the English teaching platform [50]. 


\subsection{Game design models}

In order to design a video game [51], certain elements described by some reference models must be taken into account, therefore two models that are taken into account when developing this gamified digital tool are described here. There are reference models that, on the one hand, are used specifically for the design of video games with the aim of making them entertaining and addictive; and on the other hand, those whose objective is to establish guidelines for the development of educational games taking into account learning, as main factor. A model of each type is taken into account in order to create a tool that meets both objectives.

MDA Framework: The first model of reference used in this research is the MDA framework (Mechanics-Dynamics-Aesthetics) [52]. This model is used because it seeks to make the platform look similar to a video game [53], this model also allows us to analyze and divide the design of a video game into 3 components:

- Mechanics. Related to the base components of the videogame such as: rules, player control, algorithms involved, etc. That is, all the actions that the player can perform and that allow the realization of the dynamics.

- Dynamics. Related to the context of the game like options, restrictions, competition, etc. They indicate how the mechanics are executed from the player's behavior.

- Aesthetics. It is the player's emotional response to how the game is presented. Therefore, the feelings and sensations that the video game produces in the user are involved.

Content and language integrated learning approach. Since the platform has an educational purpose, this approach is taken into account because it integrates the gamification processes with the learning of content and language. The phases of this model are: determining the teaching and learning objectives according to the needs of the student and, based on the content and language that educators wish to teach, take into account the subject of the course to finally choose the genre of the video game that more could be adapted to that theme [54] and focus only on the "emotions" since it is thanks to them that a better learning is achieved by the students.

\subsection{Gamification}

This term comes from the verb "game". Despite the increase in gamification research, a formal scientific definition is not yet established, for example according to [55] gamification consists of creating a playful experience by imitating the same psychological experience that videogames create; according to [56] gamification is the process of making an activity more like a game, and according to [57] gamification is the use of game design elements applied in non-playful contexts. All these definitions revolve around a main concept that is, to transfer the elements of design that use video games to activities outside the games, in order to capture the attention of people involved in that context. That is why, gamification is proposed to be used as an educational strategy with the aim of motivating students for an optimal learning of the English language [58]. 
This tool, designed for web systems, allows the development of different activities such as challenges, review of topics, tests for each topic, among other activities; so that the student has freedom when choosing what to do. To differentiate mechanics and dynamics by groups with similar qualities, the MDA model of reference is followed:

Mechanics: The platform has activities such as: completing the word, ordering sentences, translating sentences, relating words, relating images to words, interaction with audio and $3 \mathrm{D}$ objects, and videos in lesson format that can be accessed as many times as possible.

Player Progress: All the elements that player obtains as story progresses and are quantitative, such as: points, medals, ranking and character level.

Tasks: Activities necessary to meet some objectives like missions and minigames

Game Content: Type of activities presented by the platform such as world exploration and environments simulation.

Additional features: All those characteristics that are not included in the previous classifications like: reinforcement, map, background story, characters, enemies, tutorial, incremental difficulty, clues or advices.

Dynamics: The dynamics refer to how the user will execute the mechanics. The platform interface is shown as a $3 \mathrm{D}$ classroom where the student can interact with the objects. In this way, the student is allowed a free navigation through the various options offered by the digital tool. We include actions such as: receive medals, character selection, exploring the virtual environment, solution for mini-games, difficulty adjustment, solution clues, user's decisions and evaluation system.

Aesthetics: The students enter to a $3 \mathrm{~d}$ virtual world where they can interact with all the objects in that environment.

\subsection{Foreign languages teaching}

It is necessary to take into account the skills we need to learn in order to express ourselves correctly in English [59]. We have four skills we need to learn: speaking, which refers to the pronunciation of the words; writing, which refers to write correctly; listening, which refers to being able to understand what we hear and reading, it refers to read and understand words in another language. This research covers the four skills in presenting different activities for each of them [60].

For the teaching of foreign languages, we can find different platforms that allow, for example: content creation as interactive questionnaires [61], [62], motivate the commitment of users through mobile applications using: collaboration [63], and multiplatform systems such as "Duolingo" that has different activities implemented such as grammar and English pronunciation [64], [65]. However, a few of them includes motivation as a main factor [66].

In this research we want to give real importance to motivation, since through it we can achieve better results regarding student learning. 


\section{$3 \quad$ Methodology}

\subsection{Instruments and procedure}

The application of the study and the collection of data was carried out between March 2 and 13, 2020 during English classes at the Language Center of the "Universidad Nacional de San Agustín de Arequipa" Arequipa, Peru. The study application lasted 1 hour for 10 days, which makes a total of 10 hours per group, obtaining a total of 40 hours of study application.

The study included two tests of language proficiency carried out before and after the application of the methodology to measure real knowledge of students. Two questionnaires were also carried out regarding this new gamification and competitiveness methodology, one for each experimental and control group. These questionnaires together with descriptive statistics, Cronbach alpha, and correlations, helped us answer our research questions

Reliability: Since the study application consists of measuring qualities that are not directly observable, we used Cronbach's Alpha. It allows the measurement of qualities that are observable for each of the students and that are directly related to that nonobservable quality. It is the mean of the correlations between the variables that are part of the scale and can be related to the variances and correlations of the items [67].

For a true reliability of Cronbach's Alpha, the items need to be closely related to each other, since the maximum level of correlation is reached when the items are all the same, so ideally, Cronbach's alpha should be as close to 1 as possible. According to [68], when $\alpha>=0.7$ the instrument is really reliable, however for $\alpha<0.7$ it could indicate a weak reliability in that instrument.

\subsection{Participants}

Participants are people who enrolled in language courses offered by this institution and their age range between 16 and 35 years because it is a university center with undergraduate and postgraduate training. There was a total of 114 students. To verify that there was a correct learning, four basic level groups of students were chosen. The English teacher was the same for the 4 groups, of which two control groups and two experimentation groups were randomly selected.

Experimentation group: On first day a brief tutorial was made on how to use the platform, and the activities that the students had to do. For the study to be consistent, the teacher taught the same topics in the four groups, using the digital tool in only two groups that are the experimental groups.

Control group: The teacher taught same topics as with the experimentation groups with the only difference that the platform was not used, but a manual system of individual scoring for each correct intervention and an English book as support material. 


\section{$4 \quad$ Results}

\subsection{Regarding gamification}

Can a better learning, by using a gamified digital tool, be verified? Table 2 summarizes the result of the students' grades before and after the evaluation.

Table 2. Summary of pre and post test results.

\begin{tabular}{|c|l|c|c|c|c|}
\hline \multirow{3}{*}{ Skill } & & \multicolumn{2}{|c|}{ Pre-test } & \multicolumn{2}{c|}{ Post-test } \\
\hline \multirow{5}{*}{ Reading } & \multicolumn{1}{|c|}{ Group } & Mean & SD & Mean & SD \\
\hline \multirow{5}{*}{ Writing } & A(exper.) & 5.88 & 1.13 & 8.12 & 2.24 \\
\cline { 2 - 6 } & B(exper.) & 6.54 & 1.48 & 8.42 & 2.27 \\
\cline { 2 - 6 } & C(control) & 6.43 & 1.77 & 7.64 & 1.98 \\
\cline { 2 - 6 } & D(control) & 6.32 & 1.63 & 7.83 & 2.04 \\
\hline \multirow{5}{*}{ Listening } & A(exper.) & 4.98 & 1.01 & 6.45 & 1.49 \\
\cline { 2 - 6 } & B(exper.) & 5.40 & 1.24 & 7.81 & 1.55 \\
\cline { 2 - 6 } & C(control) & 5.48 & 1.32 & 6.43 & 1.45 \\
\cline { 2 - 6 } & D(control) & 5.41 & 1.05 & 6.89 & 1.19 \\
\cline { 2 - 6 } & A(exper.) & 4.22 & 1.08 & 6.98 & 1.86 \\
\cline { 2 - 6 } & B(exper.) & 5.68 & 1.21 & 7.66 & 2.04 \\
\cline { 2 - 6 } & C(control) & 5.47 & 1.35 & 6.84 & 1.47 \\
\cline { 2 - 6 } & D(control) & 5.33 & 1.29 & 6.93 & 1.82 \\
\hline & A(exper.) & 4.56 & 1.11 & 5.72 & 1.25 \\
\cline { 2 - 6 } & B(exper.) & 6.01 & 1.24 & 6.98 & 1.46 \\
\cline { 2 - 6 } & C(control) & 6.25 & 1.13 & 6.74 & 1.32 \\
\cline { 2 - 6 } & D(control) & 5.58 & 1.25 & 6.93 & 1.33 \\
\hline
\end{tabular}

Figure 1 represents the student's progress achieved at learning foreign languages using our methodology with support of a gamified digital tool and figure 2 represents same learning in the traditional way without use of digital tools.

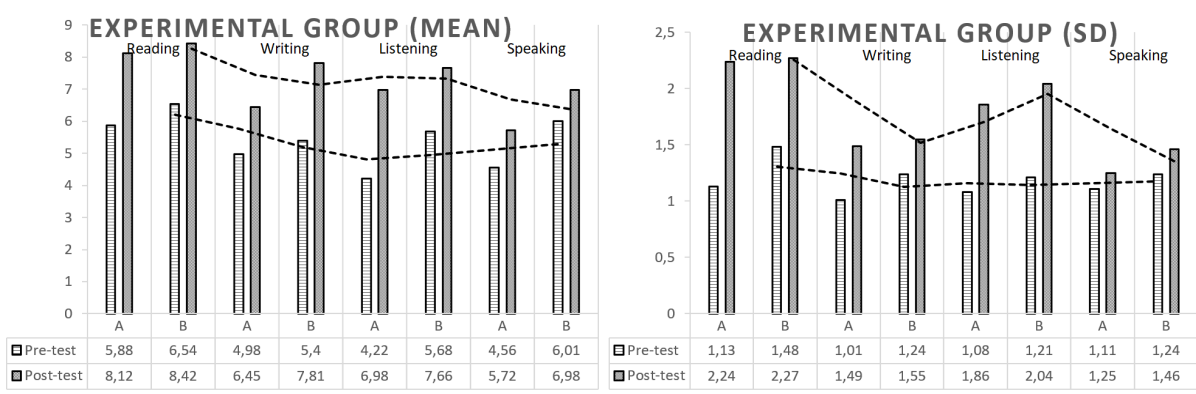

Fig. 1. Progress of experimental group achieved at learning with our gamified digital tool. 

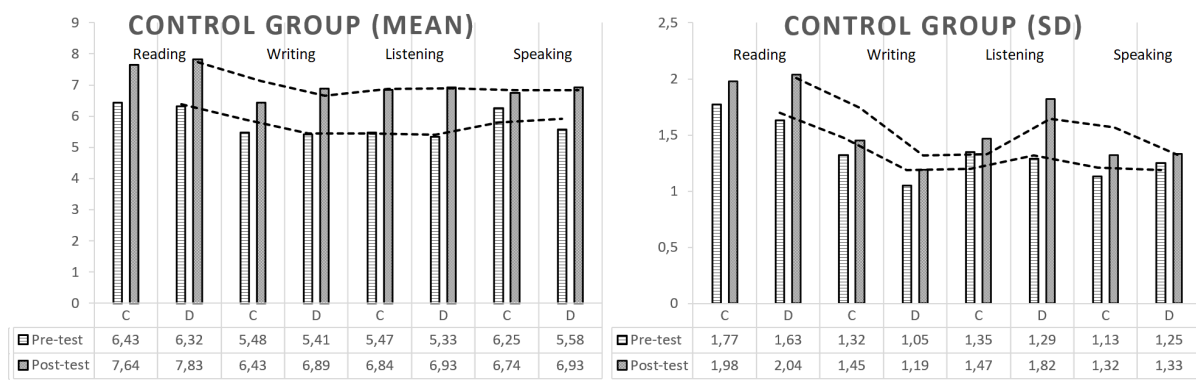

Fig. 2. Progress of control group achieved at learning with traditional methods.

Reading pre and post evaluation: Results indicate that there was truly learning in English reading skills. Both mean and standard deviation indicate that the effect of applying the digital tool was really positive for this skill. It is also evident that there was a greater learning for this skill.

Writing pre and post evaluation: It is evident that there was more learning for this skill with the use of the tool, than those who did not use it. It can be verified that there is more learning in the experimental groups than in the control groups. The platform is in Spanish language but can be configured in English language, in addition, most activities present grammar as main exercise.

Listening pre and post evaluation: The results show significant learning between the experimentation and control groups. Although the initial groups started with an almost similar average, the final results indicate that the experimental groups achieved greater learning than the control groups. The students can practice a language more constantly by listening to audios recorded by foreigners, which allows them to become more familiar with the language.

Speaking pre and post evaluation: Results indicate that, for both the experimentation group and the control group, there was learning but not as significant as in the other skills. This is because the tool provides the necessary support to reproduce and be able to listen to words recorded by a foreigner so that the student can repeat the words, however it does not have a word recognition function so that the teacher must review this skill for each of the students.

Is the expected motivation achieved in students? How do students perceive the use of these digital resources? According to Table 3 , it is shown that the students in the experimentation group who used the tool feel more interest (81.04\%) in continuing to learn, as well as feel motivated to learn English (82.76\%) and to participate in class $(79.31 \%)$. In the same way, the students of the experimentation group indicate that they feel satisfied with what they have learned $(91.38 \%)$ since they reinforced the knowledge obtained in class, with the use of the gamified digital tool. Finally, the students indicate that they felt good about the tool $(81.03 \%)$ and that it helped them work harder so they can outdo the other students $(86.21 \%)$. 
Table 3. Experimentation Group answers. $N=58 . \alpha=0.81$ ( $\alpha$ : Cronbach's Alpha).

\begin{tabular}{|l|c|c|c|c|c|}
\hline \multicolumn{1}{|c|}{ Experimentation Group } & $\begin{array}{c}\text { Strongly } \\
\text { Disagree }\end{array}$ & Disagree & $\begin{array}{c}\text { Neither Agree } \\
\text { or Disagree }\end{array}$ & Agree & $\begin{array}{c}\text { Strongly } \\
\text { Agree }\end{array}$ \\
\hline I feel interest in learning English. & $5.17 \%$ & $0.0 \%$ & $13.79 \%$ & $41.38 \%$ & $39.66 \%$ \\
\hline I participate in class. & $1.72 \%$ & $6.90 \%$ & $12.07 \%$ & $36.21 \%$ & $43.10 \%$ \\
\hline I try harder to learn and overcome others. & $3.45 \%$ & $5.17 \%$ & $5.17 \%$ & $53.45 \%$ & $32.76 \%$ \\
\hline I like to use the tool. & $8.62 \%$ & $3.45 \%$ & $6.90 \%$ & $20.69 \%$ & $60.34 \%$ \\
\hline I feel motivated to learn English. & $0.0 \%$ & $5.17 \%$ & $12.07 \%$ & $5.17 \%$ & $77.59 \%$ \\
\hline I feel satisfied with what I have learned. & $0.0 \%$ & $0.0 \%$ & $8.62 \%$ & $5.17 \%$ & $86.21 \%$ \\
\hline
\end{tabular}

These results differ from what is indicated in table 4 in which the students report that they feel some interest in learning English (51.78\%), as well as are not motivated enough to learn English (75.19\%). In addition, it is evident that the attempt to overcome others $(75.19 \%)$ is smaller than those students who do use the tool. It also shows that students are satisfied with what they have learned $(89.29 \%)$ and that they have regular participation in class (35.71\%). Finally, it is clear that students do not like to use the didactic text (50\%) because it is not dynamic at all.

Table 4. Control Group answers. $N=56 . \alpha=0.81$ ( $\alpha$ : Cronbach's Alpha).

\begin{tabular}{|l|c|c|c|c|c|}
\hline \multicolumn{1}{|c|}{ Control Group } & $\begin{array}{c}\text { Strongly } \\
\text { Disagree }\end{array}$ & Disagree & $\begin{array}{c}\text { Neither Agree } \\
\text { or Disagree }\end{array}$ & Agree & $\begin{array}{c}\text { Strongly } \\
\text { Agree }\end{array}$ \\
\hline I feel interest in learning English. & $1.79 \%$ & $3.57 \%$ & $42.86 \%$ & $37.49 \%$ & $14.29 \%$ \\
\hline I participate in class. & $3.57 \%$ & $5.36 \%$ & $55.36 \%$ & $23.21 \%$ & $12.50 \%$ \\
\hline I try harder to learn and overcome others. & $12.50 \%$ & $7.14 \%$ & $5.17 \%$ & $57.14 \%$ & $18.05 \%$ \\
\hline I like to use the book. & $17.86 \%$ & $16.07 \%$ & $16.07 \%$ & $19.64 \%$ & $30.36 \%$ \\
\hline I feel motivated to learn English. & $0.0 \%$ & $0.0 \%$ & $62.50 \%$ & $19.64 \%$ & $17.86 \%$ \\
\hline I feel satisfied with what I have learned. & $0.0 \%$ & $3.57 \%$ & $7.14 \%$ & $71.43 \%$ & $17.86 \%$ \\
\hline
\end{tabular}

\subsection{Regarding competitiveness}

Is the application of competitiveness relevant in this process? In this type of strategy, does competitiveness among students improve learning? Table 5 shows that the majority of students in the experimentation groups agree with collaborative (Aexper $=57.14 \%$, Bexper $=71.43 \%$ ) and competitive learning (Aexper $=78.57 \%$, Bexper $=76.67 \%$ ), and also indicate that competitiveness does motivate students to continue learning (Aexper $=78.57 \%$, Bexper $=83.33 \%$ ). Unlike control groups, where students prefer to learn individually (Ccontrol $=53.85 \%$, Dcontrol $=63.3 \%$ ) and in the same way they feel motivated to learn by themselves (Ccontrol $=61.54 \%$, Dcontrol $=53.33 \%$ ). 
Table 5. Results for Competitiveness survey. $\alpha=0.79$ ( $\alpha$ : Cronbach's Alpha).

\begin{tabular}{|c|c|c|c|c|c|c|}
\hline & \multicolumn{2}{|c|}{ How do you prefer to learn? } & \multicolumn{2}{c|}{$\begin{array}{c}\text { Competitiveness helps } \\
\text { improve learning? }\end{array}$} & $\begin{array}{c}\text { Do you feel motivated com } \\
\text { compete against others? }\end{array}$ \\
\hline Group & Individual & Group & Yes & No & Yes & No \\
\hline $\mathrm{A}$ (exper.) $\mathrm{N}=28$ & $42.86 \%$ & $57.14 \%$ & $78.57 \%$ & $21.43 \%$ & $78.57 \%$ & $21.43 \%$ \\
\hline $\mathrm{B}$ (exper.) $\mathrm{N}=30$. & $28.57 \%$ & $71.43 \%$ & $76.67 \%$ & $23.33 \%$ & $83.33 \%$ & $16.67 \%$ \\
\hline $\mathrm{C}$ (control) $\mathrm{N}=26$ & $53.85 \%$ & $46.15 \%$ & $46.15 \%$ & $53.85 \%$ & $61.54 \%$ & $38.46 \%$ \\
\hline $\mathrm{D}$ (control) $\mathrm{N}=30$ & $63.30 \%$ & $36.7 \%$ & $56.67 \%$ & $43.33 \%$ & $53.33 \%$ & $46.67 \%$ \\
\hline
\end{tabular}

\section{Discussion and Conclusion}

In this study, a methodology, that applied gamification to a digital support material tool, was used to improve students' language learning. This methodology consisted of the use of gamification elements and activities based on competitiveness so that students feel committed to learning in a more dynamic way than traditional. These gamification elements provided the necessary feedback for the student to be motivated to continue with the course while being able to compete against their peers to reach the first places in virtual competitions. It has been shown this methodology to be effective because, for this case, language learning requires the students to relate foreign words to words they know in their language, so the use of a graphical tool should be essential.

In addition, the competitiveness between students was established because, on the one hand they felt motivated to compete against others and on the other hand, they wanted to overcome themselves.

As shown in Tables 4, 5 and 6, our Cronbach's alpha coefficient is greater than 0.7 $(\alpha>=0.81$ for gamification questionnaire and $\alpha>=0.79$ for competitiveness questionnaire), which indicates that the questionnaires used are truly reliable as well as the information that was collected. This confirms that both gamification and competitiveness are important factors when applying methodologies that include digital tools to support learning of specific topics.

Results have shown that the use of digital resources as support material in class is effective. Students who use these tools feel more motivated to learn than those who do not use them and this is because learning is done dynamically, and it is an innovative method. The use of gamification elements generates in the students a commitment towards the course and its completion. Regardless of age, we consider important the use of these as they offer greater participation to those students who are not interested in participating. In this case we can verify that the use of these tools effectively improves learning with the appropriate methodology. Furthermore, the motivation and personal satisfaction of the students are also a great factor to be considered when developing these tools. Nowadays, people do most activities digitally as they prefer a dynamic virtual environment. Finally, the competitive format presented by the platform generates in the students a feeling of self-improvement and to outdo the other students since they can compete with each other. 


\section{Acknowledgement}

This work was supported and financed by "Universidad Nacional de San Agustín de Arequipa" through "Vicerrectorado Académico de Investigación", project: TP-212019-UNSA. The authors would like to thank to the application research participants, also to Ricardo Casañ Pitarch for the invaluable knowledge acquired and for the advices provided.

\section{$7 \quad$ References}

[1] D. Balasanyan, "Publishing Research in English as an Additional Language," Univ. Adelaide Press, vol. 6, no. 2, pp. 260-264, 2017.

[2] L. J. Bracken and E. A. Oughton, “'What do you mean?' The importance of language in developing interdisciplinary research,” Trans. Inst. Br. Geogr., vol. 31, no. 3, pp. 371-382, 2006. https://doi.org/10.1111/j.1475-5661.2006.00218.x

[3] N. Evans and S. C. Levinson, "The myth of language universals: Language diversity and its importance for cognitive science,” Behav. Brain Sci., vol. 32, no. 5, pp. 429-448, 2009. https://doi.org/10.1017/s0140525x0999094x

[4] M. Prensky, "Digital Natives, Digital Inmigrants," MCB Univ. Press, vol. 9, no. 5, 2001.

[5] V. Kuperman, Z. Estes, M. Brysbaert, and A. B. Warriner, "Emotion and language: Valence and arousal affect word recognition,” J. Exp. Psychol. Gen., vol. 143, no. 3, pp. 1065-1081, 2014. https://doi.org/10.1037/a0035669

[6] A. J. Moeller and T. Catalano, "Foreign Language Teaching and Learning," Int. Encycl. Soc. Behav. Sci. Second Ed., pp. 327-332, 2015.

[7] M. J. Eady and L. Lockyer, "Tools for learning: technology and teaching strategies," Learn. to Teach Prim. Sch., no. January 2013, p. 71, 2013.

[8] T. Teo, "Modelling technology acceptance in education: A study of pre-service teachers," Comput. Educ., vol. 52, no. 2, pp. 302-312, 2009. https://doi.org/10.1016/j.compedu.2008. $\underline{08.006}$

[9] E. J. Marchiori, J. Torrente, Á. Del Blanco, P. Moreno-Ger, P. Sancho, and B. FernándezManjón, "A narrative metaphor to facilitate educational game authoring," Comput. Educ., vol. 58, no. 1, pp. 590-599, 2012. https://doi.org/10.1016/j.compedu.2011.09.017

[10] P. S. Lengyel, "Can the Game-Based Learning Come? Virtual Classroom in Higher Education of 21st Century What is The Good Game Like? Are There Good and Motivating Games to be Used? Features of The Educational," Int. J. Emerg. Technol. Learn., vol. 15, pp. 112-126, 2020. https://doi.org/10.3991/ijet.v15i02.11521

[11] M. E. Parra-González, J. L. Belmonte, A. Segura-Robles, and A. F. Cabrera, "Active and emerging methodologies for ubiquitous education: Potentials of flipped learning and gamification," Sustain., vol. 12, no. 2, 2020. https://doi.org/10.3390/su12020602

[12] M. Sailer and M. Sailer, "Gamification of in-class activities in flipped classroom lectures," Br. J. Educ. Technol., vol. 0, no. 0, pp. 1-16, 2020. https://doi.org/10.1111/bjet.12948

[13] S. Martin, G. Diaz, E. Sancristobal, R. Gil, M. Castro, and J. Peire, "New technology trends in education: Seven years of forecasts and convergence," Comput. Educ., vol. 57, no. 3, pp. 1893-1906, 2011. https://doi.org/10.1016/j.compedu.2011.04.003

[14] M. Gomez-Zermeno and L. Aleman, "Research Analysis on Mooc Course Dropout and R,” Turkish Online J. Distance Educ., vol. 17, no. 4, pp. 3-14, 2016. https://doi.org/10.177 $\underline{18 / \text { tojde. } 23429}$ 
[15] S. Eddine, J. EL, and Y. LEFDAOUI, "Learners' Attitudes Towards Extended-Blended Learning Experience Based on the S2P Learning Model,” Int. J. Adv. Comput. Sci. Appl., vol. 6, no. 10, pp. 70-78, 2015. https://doi.org/10.14569/ijacsa.2015.061010

[16] M. M. K. Elsherbiny and R. H. Raya, "Game-based learning through mobile phone apps: effectively enhancing learning for social work students," Soc. Work Educ., vol. 00, no. 00, pp. 1-18, 2020. https://doi.org/10.1080/02615479.2020.1737665

[17] Z. Zainuddin, M. Shujahat, H. Haruna, and S. K. W. Chu, "The role of gamified e-quizzes on student learning and engagement: An interactive gamification solution for a formative assessment system," Comput. Educ., vol. 145, p. 103729, 2020. https://doi.org/10.1016/j. compedu.2019.103729

[18] E. J. Cohen, P. E. G. A. Delage, R. B. Alencar, and A. B. Menezes, "Percepção Dos Estudantes Em Relação a Uma Experiência De Gamificação Na Disciplina De Psicologia E Educação Inclusiva," Holos, vol. 1, pp. 1-15, 2020. https://doi.org/10.15628/holos.2020.75 $\underline{97}$

[19] J. Friedrich, M. Becker, F. Kramer, M. Wirth, and M. Schneider, "Incentive design and gamification for knowledge management," J. Bus. Res., no. February 2019.

[20] S. Butler and D. T. Ahmed, "Gamification to engage and motivate students to achieve computer science learning goals," Proc. - 2016 Int. Conf. Comput. Sci. Comput. Intell. CSCI 2016, pp. 237-240, 2017. https://doi.org/10.1109/csci.2016.0053

[21] M. M. Fernandez-Antolin, J. M. del Río, and R. A. Gonzalez-Lezcano, "The use of gamification in higher technical education: perception of university students on innovative teaching materials,” Int. J. Technol. Des. Educ., no. 0123456789, 2020. https://doi.org/10. 1007/s10798-020-09583-0

[22] M. Sailer, J. U. Hense, S. K. Mayr, and H. Mandl, "How gamification motivates: An experimental study of the effects of specific game design elements on psychological need satisfaction," Comput. Human Behav., vol. 69, pp. 371-380, 2017. https://doi.org/10.1016/j.c hb.2016.12.033

[23] L. Da Rocha Seixas, A. S. Gomes, and I. J. De Melo Filho, "Effectiveness of gamification in the engagement of students," Comput. Human Behav., vol. 58, pp. 48-63, 2016. https:// doi.org/10.1016/j.chb.2015.11.021

[24] Ş. Ç. Özhan and S. A. Kocadere, "The Effects of Flow, Emotional Engagement, and Motivation on Success in a Gamified Online Learning Environment," J. Educ. Comput. Res., vol. 57, no. 8, pp. 2006-2031, 2020. https://doi.org/10.1177/0735633118823159

[25] A. Ortega-Arranz, E. Er, A. Martínez-Monés, M. L. Bote-Lorenzo, J. I. Asensio-Pérez, and J. A. Muñoz-Cristóbal, "Understanding student behavior and perceptions toward earning badges in a gamified MOOC," Univers. Access Inf. Soc., vol. 18, no. 3, pp. 533-549, 2019. https://doi.org/10.1007/s10209-019-00677-8

[26] K. Ofosu-Ampong, R. Boateng, T. Anning-Dorson, and E. A. Kolog, "Are we ready for Gamification? An exploratory analysis in a developing country," Educ. Inf. Technol., vol. 25, no. 3, pp. 1723-1742, 2020. https://doi.org/10.1007/s10639-019-10057-7

[27] M. Aparicio, T. Oliveira, F. Bacao, and M. Painho, "Gamification: A key determinant of massive open online course (MOOC) success," Inf. Manag., vol. 56, no. 1, pp. 39-54, 2019. https://doi.org/10.1016/j.im.2018.06.003

[28] N. P. A. Resmayani and I. N. T. D. Putra, "Gamification: Using Kahoot! to Make Students Love the Class from the Very Beginning," Linguist. ELT J., vol. 7, no. 1, pp. 10-18, 2020.

[29] I. Danka, "Motivation by gamification: Adapting motivational tools of massively multiplayer online role-playing games (MMORPGs) for peer-to-peer assessment in connectivist massive open online courses (cMOOCs)," Int. Rev. Educ., vol. 66, no. 1, pp. 75-92, 2020. https://doi.org/10.1007/s11159-020-09821-6 
[30] C. Hursen and C. Bas, "International journal of emerging technologies in learning.," Int. J. Emerg. Technol. Learn., vol. 14, no. 01, pp. 4-23, 2019.

[31] A. Álvaro-Tordesillas, M. Alonso-Rodríguez, I. Poza-Casado, and N. Galván-Desvaux, "Gamification experience in the subject of descriptive geometry for architecture," Educ. XX1, vol. 23, no. 1, pp. 373-408, 2020. https://doi.org/10.5944/educxx1.23591

[32] L. F. Daghestani, L. F. Ibrahim, R. S. Al-Towirgi, and H. A. Salman, “Adapting gamified learning systems using educational data mining techniques," Comput. Appl. Eng. Educ., vol. 28 , no. 3, pp. 568-589, 2020. https://doi.org/10.1002/cae.22227

[33] A. MOKEDDEM, M. PLAISENT, and B. PROSPER, "Learning with the Games: a Competitive Environment based on Knowledge,” J. e-Learning High. Educ., vol. 2019, pp. 1-6, 2019.

[34] D. Šimek and D. Kobal Grum, "Competitiveness and motivation for education in selfhandicapping,” Stud. Psychol. (Bratisl)., vol. 53, no. 1, pp. 83-96, 2011.

[35] T. Y. Kim, Y. Kim, and J. Y. Kim, "Role of Resilience in (De)Motivation and Second Language Proficiency: Cases of Korean Elementary School Students,” J. Psycholinguist. Res., vol. 48, no. 2, pp. 371-389, 2019. https://doi.org/10.1007/s10936-018-9609-0

[36] F. Wenzheng, T. Jie, L. Tracy Xiao, Z. Shuhuai, and G. Jian, "Understanding Dropouts in MOOCs," Proc. 33rd AAAI Conf. Artif. Intell., pp. 1-8, 2019.

[37] H. Y. Cheung and A. W. H. Chan, "The relationship of competitiveness motive on people's happiness through education,” Int. J. Intercult. Relations, vol. 35, no. 2, pp. 179-185, 2011. https://doi.org/10.1016/j.ijintrel.2010.11.008

[38] C. A. Torres, "Solidarity and competitiveness in a global context: Comparable concepts in global citizenship education?” Int. Educ. J., vol. 14, no. 2, pp. 22-29, 2015.

[39] J. Hamari, A. Malik, J. Koski, and A. Johri, "Uses and Gratifications of Pokémon Go: Why do People Play Mobile Location-Based Augmented Reality Games?" Int. J. Hum. Comput. Interact., vol. 35, no. 9, pp. 804-819, 2019. https://doi.org/10.1080/10447318.20 $\underline{18.1497115}$

[40] J. Hamari and L. Keronen, "Why do people play games? A meta-analysis," Int. J. Inf. Manage., vol. 37, no. 3, pp. 125-141, 2017. https://doi.org/10.1016/j.ijinfomgt.2017.01.0 $\underline{06}$

[41] H. Herwinarso, B. Untung, J. V. D. Wirjawan, and E. Pratidhina, "Development of Android App to Assist High School Students in Learning Physics Quantities and Measurement Principles," TEM J., vol. 9, no. 1, pp. 292-295, 2020.

[42] R. M. Ryan and E. L. Deci, "Intrinsic and Extrinsic Motivations: Classic Definitions and New Directions," vol. 67, pp. 54-67, 2000. https://doi.org/10.1006/ceps.1999.1020

[43] A. Fuentes Cabrera, M. E. Parra-González, J. López Belmonte, and A. Segura-Robles, "Educational Potentials of Flipped Learning in Intercultural Education as a Transversal Resource in Adolescents," Religions, vol. 11, no. 1, p. 53, 2020. https://doi.org/10.3390/re $\underline{111010053}$

[44] R. M. Ryan and E. L. Deci, "On happiness and human potentials: A Review of Research on Hedonic and," 2001.

[45] D. R. Broom, K. Y. Lee, M. H. S. Lam, and S. W. Flint, "Gotta catch 'em all or not enough time: Users motivations for playing Pokémon GoTM and non-users' reasons for not installing," Heal. Psychol. Res., vol. 7, no. 1, pp. 1-9, 2019. https://doi.org/10.4081/hp r.2019.7714

[46] P. Trofimovich and E. Gatbonton, "Repetition and focus on form in processing L2 Spanish words: Implications for pronunciation instruction,” Mod. Lang. J., vol. 90, no. 4, pp. 519535, 2006. https://doi.org/10.1111/j.1540-4781.2006.00464.X 
[47] M. D. Dickey, "Engaging by design: How engagement strategies in popular computer and video games can inform instructional design,” Educ. Technol. Res. Dev., vol. 53, no. 2, pp. 67-83, 2005. https://doi.org/10.1007/bf02504866

[48] J. R. Fanfarelli, "Impact of narrative and badging on learning and engagement in a psychology learning game,” Br. J. Educ. Technol., vol. 51, no. 2, pp. 387-419, 2020. https:// doi.org/10.1111/bjet.12838

[49] R. Casañ Pitarch, "Gamifying Content and Language Integrated Learning with Serious Videogames,” J. Lang. Educ., vol. 3, no. 3, pp. 107-114, 2017. https://doi.org/10.17323/24 11-7390-2017-3-3-107-114

[50] H. Dehghanzadeh, H. Fardanesh, J. Hatami, E. Talaee, and O. Noroozi, "Using gamification to support learning English as a second language: a systematic review," Comput. Assist. Lang. Learn., vol. 0, no. 0, pp. 1-24, 2019. https://doi.org/10.1080/09588221.2019.16 $\underline{48298}$

[51] N. Ratnawati, S. Sukamto, I. N. Ruja, and N. Wahyuningtyas, "'Defense of the Ancients', Gamification in Learning: Improvement of Student's Social Skills," Int. J. Emerg. Technol. Learn., vol. 15, no. 07, p. 132, 2020. https://doi.org/10.3991/ijet.v15i07.13221

[52] G. P. Kusuma, E. K. Wigati, Y. Utomo, and L. K. Putera Suryapranata, "Analysis of Gamification Models in Education Using MDA Framework," Procedia Comput. Sci., vol. 135, pp. 385-392, 2018. https://doi.org/10.1016/j.procs.2018.08.187

[53] R. Hunicke, M. Leblanc, and R. Zubek, "MDA: A formal approach to game design and game research," AAAI Work. - Tech. Rep., vol. WS-04-04, pp. 1-5, 2004.

[54] R. Casañ-Pitarch, "Storyline-based videogames in the FL classroom," Digit. Educ. Rev., no. 31, pp. 80-92, 2017.

[55] J. Hamari, J. Koivisto, and H. Sarsa, "Does gamification work? - A literature review of empirical studies on gamification,” Proc. Annu. Hawaii Int. Conf. Syst. Sci., pp. 30253034, 2014. https://doi.org/10.1109/hicss.2014.377

[56] K. Werbach, "(Re)defining gamification: A process approach,” Lect. Notes Comput. Sci. (including Subser. Lect. Notes Artif. Intell. Lect. Notes Bioinformatics), vol. 8462 LNCS, pp. 266-272, 2014. https://doi.org/10.1007/978-3-319-07127-5 23

[57] S. Deterding, D. Dixon, R. Khaled, and L. Nacke, "From game design elements to gamefulness: Defining 'gamification,"” Proc. 15th Int. Acad. MindTrek Conf. Envisioning Futur. Media Environ. MindTrek 2011, pp. 9-15, 2011. https://doi.org/10.1145/2181037.218 $\underline{1040}$

[58] M. Purgina, M. Mozgovoy, and J. Blake, "WordBricks: Mobile Technology and Visual Grammar Formalism for Gamification of Natural Language Grammar Acquisition," J. Educ. Comput. Res., vol. 58, no. 1, pp. 126-159, 2020. https://doi.org/10.1177/073563311 $\underline{9833010}$

[59] A. Paran, "Language skills: Questions for teaching and learning," ELT J., vol. 66, no. 4, pp. 450-458, 2012. https://doi.org/10.1093/elt/ccs045

[60] M. C. Bueno-Alastuey and M. V. López Pérez, "Evaluation of a blended learning language course: students' perceptions of appropriateness for the development of skills and language areas," Comput. Assist. Lang. Learn., vol. 27, no. 6, pp. 509-527, 2014. https://doi.org/10. 1080/09588221.2013.770037

[61] E. G. L. Medina and C. P. R. Hurtado, "Kahoot! A Digital Tool for Learning Vocabulary in a language classroom,” Rev. Publicando, vol. 4, no. 12, pp. 441-449, 2017.

[62] D. R. Sanchez, M. Langer, and R. Kaur, "Gamification in the classroom: Examining the impact of gamified quizzes on student learning," Comput. Educ., vol. 144, no. October 2018, p. 103666, 2020. https://doi.org/10.1016/j.compedu.2019.103666 
[63] O. De Troyer, J. Maushagen, R. Lindberg, and D. Breckx, "Playful learning with a location-based digital card environment: A promising tool for informal, non-formal, and formal learning," Inf., vol. 11, no. 3, 2020. https://doi.org/10.3390/info11030157

[64] P. Munday, "The case for using DUOLINGO as part of the language classroom experience / DUOLINGO como parte del curriculum de las clases de lengua extranjera," RIED. Rev. Iberoam. Educ. a Distancia, vol. 19, no. 1, pp. 83-101, 2015. https://doi.org/10.5944/ried.1 9.1.14581

[65] J. R. Rachels and A. J. Rockinson-Szapkiw, "The effects of a mobile gamification app on elementary students' Spanish achievement and self-efficacy," Comput. Assist. Lang. Learn., vol. 31, no. 1-2, pp. 72-89, 2018. https://doi.org/10.1080/09588221.2017.1382536

[66] A. I. Wang and R. Tahir, "The effect of using Kahoot! for learning - A literature review," Comput. Educ., vol. 149, p. 103818, 2020. https://doi.org/10.1016/j.compedu.2020.103818

[67] K. S. Taber, "The Use of Cronbach's Alpha When Developing and Reporting Research Instruments in Science Education,” Res. Sci. Educ., vol. 48, no. 6, pp. 1273-1296, 2018. https://doi.org/10.1007/s11165-016-9602-2

[68] C. Jum and Nunnaly, "Most Lucid and Systematic Presentation of Modern Psychometrics," Psychom. Theory, vol. 1, pp. 196-198, 1968.

\section{Authors}

Norman Patrick Harvey Arce is a Peruvian computer scientist and systems engineer. He has studies in Computer Science (2018) at "Universidad Nacional de San Agustín de Arequipa", Industrial Electrotechnics (2013) and Systems Engineering (2016). He is currently developing an educational platform for foreign languages, with international consultancies and trainings from Spain and Brazil.

Ana Maria Cuadros Valdivia, graduated in Computer Engineering at "Universidad Católica San Pablo" (2004) and master's degree in Computer Science and Computational Mathematics from the Institute of Mathematical and Computer Sciences (2007). Since 2008 he has been teaching at "Universidad Católica San Pablo". Now working at "Universidad Nacional de San Agustín de Arequipa" as HCI principal teacher Experience in the area of Graphic Computing, with an emphasis on Information Visualization, working mainly on the following topics: human computer interaction, visual representations of document sets, data mining, visual data mining, exploration and interaction of large multi-dimensional volumes.

Article submitted 2020-06-07. Resubmitted 2020-07-13. Final acceptance 2020-07-16. Final version published as submitted by the authors. 